\title{
Properties of the Tumor Suppressor Gene Brca2 in the Cat
}

\author{
Toshina OONUMA ${ }^{1)}$, Masami MORIMATSU ${ }^{1) *}$, Kazuhiko OCHIAI $^{1)}$ and Bunei SYUTO ${ }^{1)}$ \\ ${ }^{1)}$ Laboratory of Veterinary Physiolosy, Faculty of Agriculture, Iwate University, Morioka 020-8550, Japan
}

(Received 14 April 2003/Accepted 16 June 2003)

ABSTRACT. Mammary tumors are common in cats. As mutations in human Brca2 confer an increased risk of breast cancer, the full-length cDNA of the feline homologue of Brca2 was sequenced to obtain a basis for studying the relationship between its function and susceptibility to mammary tumors. The feline Brca2 cDNA is $10 \mathrm{~kb}$ long, and encodes 3,371 amino acids. The amino acid sequence of fel ine Brca2 shares low homology with the Brca2 of other mammals, e.g., 53\% homology with the murine protein. Analysis of the expression pattern of the feline Brca2 gene revealed that, as previously reported for other mammals, it is transcribed in various tissues, including the mammary gland.

KEY WORDS: Brca2, feline, mammary tumor.

J. Vet.Med. Sci. 65(10): 1123-1126, 2003

Breast tumors are more common in the female cat than in any other domestic species except the dog [6], and account for $17 \%$ of the neoplasms in female cats [17]. The percentage of breast tumors that are malignant is higher in the cat $(86 \%)$ than in the dog $(42 \%)$. Adenocarcinoma predominates among malignant mammary tumors in cats [11], and in many biological and histological aspects (e.g., rapid growth, high metastatic rates to distant organs at an early stage, and poor prognosis) it resembles adenocarcinoma in women more closely than does experimentally induced cancer in inbred laboratory animals $[10,24]$. In both humans and cats, treatment of advanced breast cancer is often futile and disfiguring, making early detection a high priority in the management of this disease.

Germline mutation of the Brca2 gene in humans carries a high risk of developing breast cancer [16]. The Brca2 gene appears to act as a tumor-suppressor gene, in that carriers show loss or mutation of the wild-type allele within tumors (loss of heterozygosity). After sequencing the full-length cDNA, many reports have described mutational analyses of the gene in families and in primary tumors $[9,12,21]$. The Brca2 cDNA sequence, which predicts a large protein of 3,418 amino acids, shows no obvious homology to any other protein $[5,26]$. The tumor suppressor function of Brca2 appears to be associated with its biochemical interaction with Rad51 protein, which plays a central role in maintaining chromosome stability and double-strand break repair [1, $14,19,25]$.

To establish a basis for diagnostic methods and for using as a prognostic factor, and to understand the role of Brca 2 in mammary tumors, we report the sequence of feline Brca2 cDNA. We also studied the pattern of gene expression.

The polymerase chain reaction (PCR) and direct sequencing were performed using the primers shown in Table 1. The amplified fragments are shown in Fig. 1A. The primer sequences were designed from reported human (GenBank

\footnotetext{
* Correspondence to: Morimatsu, M., Laboratory of Veterinary Physiology, Faculty of Agriculture, Iwate University, Morioka 020-8550, Japan.
}

accession No.: NM_000059), murine (U65594), and canine (AB043895) sequences, or designed from the feline sequence that we obtained using these primers. Total RNA was extracted from the testis of a mongrel male cat using TRIzol reagent (Invitrogen, Leek, The Netherlands). Total RNA $(2 \mu \mathrm{g})$ was denatured at $70^{\circ} \mathrm{C}$ for $10 \mathrm{~min}$, cooled immediately, and reverse transcribed using 200 units of MMLV reverse transcriptase (Invitrogen), 25 pmol of random primer, and $10 \mathrm{nmol}$ dNTPs in a total volume of $20 \mu \mathrm{l}$ at $37^{\circ} \mathrm{C}$ for $50 \mathrm{~min}$. After heating at $75^{\circ} \mathrm{C}$ for $15 \mathrm{~min}, \mathrm{PCR}$ amplification was performed with 2.5 units of Taq polymerase or KOD Plus (TOYOBO, Osaka, Japan), $1.5 \mathrm{mM}$ $\mathrm{MgCl}_{2}, 20 \mathrm{nmol}$ of dNTPs, and $20 \mathrm{pmol}$ of primers. PCR was conducted for 30 cycles, each consisting of denaturation at $94^{\circ} \mathrm{C}$ for $30 \mathrm{sec}$, annealing at $53^{\circ} \mathrm{C}$ for $30 \mathrm{sec}$, and extension at $68^{\circ} \mathrm{C}$ for $2.5 \mathrm{~min}$. PCR amplification of the 5' and 3' cDNA ends of feline Brca2 was performed with the RACE system (Invitrogen), and 10 pmol of the target-specific primers shown in Fig. 1. For the RACE system, PCR was conducted for 30 cycles, each consisting of denaturation at $94^{\circ} \mathrm{C}$ for $30 \mathrm{sec}$, annealing at $55^{\circ} \mathrm{C}$ for $30 \mathrm{sec}$, and extension at $72^{\circ} \mathrm{C}$ for $5 \mathrm{~min}$. The sequences were determined by direct sequencing using BigDye Terminator Cycle sequencing reagents and an Applied Biosystem Sequencer 310 (Perkin Elmer, Tokyo, Japan).

To explore the tissue distribution of feline Brca2, the RTreaction was performed for total RNA extracted from testis, prostate, ovary, mammary gland, spleen, thymus, lymph node, heart, liver, kidney, and brain. PCR amplification was performed with the primers shown in Fig. 1, with forward primer No. 8 and reverse primer No. 9. RT-PCR was performed as described for cDNA sequencing, except that $1 \mu \mathrm{g}$ of total RNA was used. The PCR products were electrophoresed on $1 \%$ agarose gels and stained with ethidium bromide. Glyceraldehyde-phosphate dehydrogenase (GPDH) was used as a control.

The open reading frame of the feline Brca 2 cDNA was 10 $\mathrm{kb}$ long, encoding a large protein of 3,371 amino acids (accession No. AB107955). The feline Brca2 protein 
Table 1. Profiles of the PCR products and primers used in PCR and sequencing of feline Brca2

\begin{tabular}{|c|c|c|c|c|}
\hline Fragment number & Primer & Nucleotides & Sequence (5' to $\left.3^{\prime}\right)$ & Fragments size \\
\hline I & Reverse & $148-167$ & TAACTGATTTTATATCCAGA & 168 \\
\hline \multirow[t]{2}{*}{ II } & Forward & 79-98 & $\overline{\text { ATAAGCCTCAATTGGTTTGA }}$ & 586 \\
\hline & Reverse & $645-664$ & AGCTTTTAAAAATAGCAGTA & \\
\hline \multirow[t]{2}{*}{ III } & Forward & $462-481$ & GCTTATTCATACACCGAGGC & 945 \\
\hline & Reverse & $1387-1406$ & TCATGAGATTCAAGACACTG & \\
\hline \multirow[t]{2}{*}{ IV } & Forward & $1254-1273$ & CCTCATAATCACGGATAAAG & 638 \\
\hline & Reverse & $1872-1891$ & GCAATTAACCTGAATCAGCA & \\
\hline \multirow[t]{2}{*}{$\mathrm{V}$} & Forward & $1620-1239$ & AGAGGATTCTTTATGTACAA & 1346 \\
\hline & Reverse & $2946-2965$ & ACAGTCTTGCCCAATTATCC & \\
\hline \multirow[t]{2}{*}{ VI } & Forward & 2814-2833 & GAACATAGATGATCTTACAG & 659 \\
\hline & Reverse & 3453-3472 & CATCTTTCTGTTCCTCAGGA & \\
\hline \multirow[t]{2}{*}{ VII } & Forward & $3283-3302$ & TCAAATCGTAATTTAACTCC & 891 \\
\hline & Reverse & $4154-4173$ & AGCTTTCATAACTTCCAAAC & \\
\hline \multirow[t]{2}{*}{ VIII } & Forward & $4034-4053$ & TTCATAAAGAAGAAAATGGC & 2040 \\
\hline & Reverse & $6054-6073$ & CTAGTATTCCCTTAACTTTG & \\
\hline \multirow[t]{2}{*}{ IX } & Forward & 5978-5997 & ATTTACTATCATCTGCTTTC & 1682 \\
\hline & Reverse & $7640-7659$ & ACCTGGGGTGTCACACAGAG & \\
\hline \multirow[t]{2}{*}{$X$} & Forward & 7619-7640 & GAAAAGAAGAATTTTATAGGGC & 1512 \\
\hline & Reverse & $9111-9130$ & AATTATGGCATTCATCTGAC & \\
\hline \multirow[t]{2}{*}{ XI } & Forward & $8917-8936$ & GCAACAAAGAAAACTCAGTA & 595 \\
\hline & Reverse & 9492-9511 & GATAATTCATCTCATTATTG & \\
\hline XII & Forward & $9423-9442$ & CTATGCTTCAGAGCCACACA & 1058 \\
\hline \multicolumn{5}{|l|}{ Sequencing primer } \\
\hline No. 1 & Forward & 2029-2048 & GATCTTGATTATAAAGAAGC & \\
\hline No. 2 & Forward & 4437-4456 & TCATGGAGAAATGGAAATAC & \\
\hline No. 3 & Reverse & $5323-5342$ & GAAACCGTCACTTTAATGGC & \\
\hline No. 4 & Forward & $6406-6425$ & TGGAAATTGGAAACTGAAGC & \\
\hline No. 5 & Reverse & $7099-7118$ & TCTTCCACATGAGTATTCTT & \\
\hline No. 6 & Forward & $8000-8019$ & ATGGATGGTATGCCATTAAG & \\
\hline No. 7 & Forward & $8307-8326$ & ATACCCCATACAGTGGATGG & \\
\hline No. 8 & Forward & 9747-9766 & TGGCACCAAATATGAAACAC & \\
\hline No. 9 & Reverse & $10250-10269$ & $\underline{\text { ATCAAAGCACAGAGGCAGAC }}$ & \\
\hline
\end{tabular}

For the RACE fragments (fragments I and XII) only the specific primers are shown. Under lined sequences are obtained from feline Brca2 sequence.

showed $68,53,78$, and $32 \%$ homology with the human [21], murine [18], canine [15], and chicken Brca2 proteins [20, 23], respectively. The degree of homology for feline and other mammals is low, but similar to values reported previously for mouse and human Brca2 proteins [18]. Thus, the degree of homology is sufficient to deem that the PCR product obtained in this study is feline Brca2. In fact, we have not produced any other homologous PCR products using our PCR procedure. Feline Brca2 includes predicted functional domains, such as BRC repeats [3], P/CAF interacting motif [8], three of NLSs [27], BLAT domain [23], and C-terminus Rad51 binding domain [14, 19], that are conserved in the species reported to date (Fig. 1B). The tissue distribution of feline Brca 2 was investigated by RT-PCR, using RNA from brain, lymph node, thymus, heart, liver, kidney, testis, mammary gland, prostate, ovary, and uterus (Fig. 2). As previously reported for the human and mouse, Brca2 was expressed in the mammary gland, testis, ovary, uterus, thymus, and brain. Because the functional domains are important for the tumor suppresser function of human Brca2 [4, 8, 23, 27], and because feline Brca2 was expressed in mam- mary gland, it may be possible that feline Brca2 also acts as tumor suppressor in the cat.

Since the human Brca2 mutations that cause mammary tumors occur throughout its sequence [22], it was deemed necessary to obtain the entire feline Brca 2 sequence. Therefore, we amplified the full-length feline Brca2 cDNA by RT-PCR. This should permit the genetic analysis of feline breast cancer, to determine whether mutations of this gene are also responsible for a predisposition to mammary tumors in felines. If so, this technique will be useful for genetic diagnosis of hereditary mammary tumors in the cat. Since it has been reported that some feline breeds have twice the risk of developing mammary carcinoma as all breeds combined [11], the presence of a mammary tumor susceptibility gene in the cat, such as Brca2, may be possible. Loss of Brca2 expression in the cat may cause tumors, since the human homologue is established as a tumor suppressor. Conversely, overexpression of Brca2 in human sporadic breast cancer is reported to predict a poor prognosis $[2,7]$. In addition to several proposed prognostic factors for feline mammary tumors [13], such as the age of onset and the diameter 
A

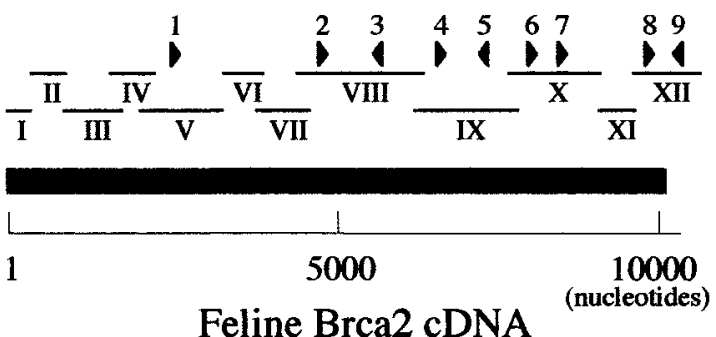

B

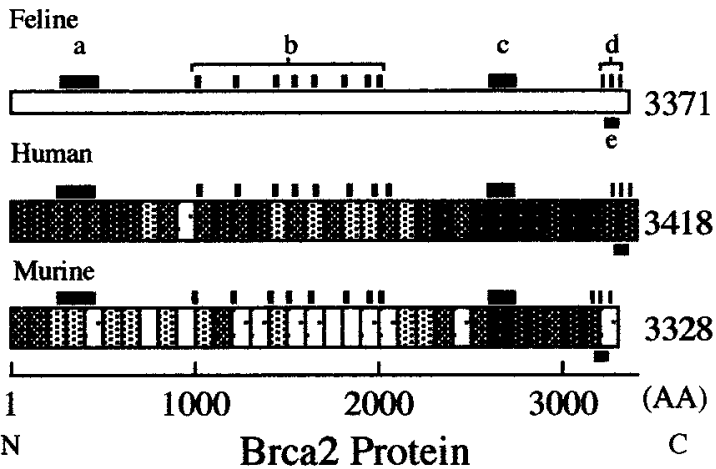

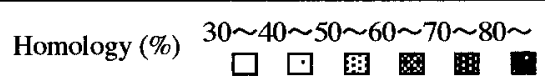

Fig. 1. The schema of cDNA or protein of feline Brca2. (A) Amplification products of feline Brca2 cDNA. Twelve cDNA fragments were amplified from feline testis RNA. The Roman numerals I to XII represent the fragments covering the full-length of the feline Brca2 cDNA; the Arabic numerals 1 to 9 and the triangles represent the sequencing primers. The respective numbers correspond to those in Table 1. (B) The upper open bar represents feline Brca2 protein, and the solid bars show the predicted functional domain of feline Brca2, P/CAF interacting motif (a), eight of BRC repeats (b), BLAT domain (c), three of nuclear localization signals (NLSs, d) and C-terminus Rad51 binding domain (e). The middle bar is the human Brca2 protein and the lower one is the murine Brca2 protein. The shaded boxes represent the degree of homology between these proteins, which were divided into 100 amino-acid blocks and compared. AA: amino acids.

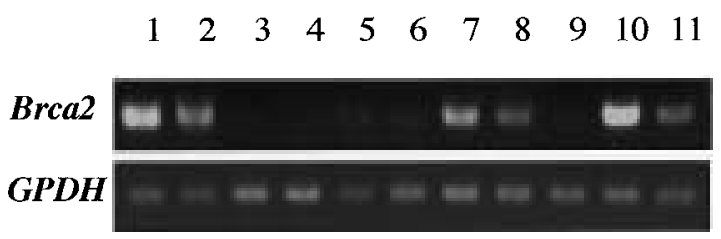

Fig. 2. Expression of feline Brca2. Total RNA from various tissues was used for RT-PCR. Lane 1: brain, lane 2: thymus, lane 3: lymph node, lane 4: heart, lane 5: liver, lane 6: kidney, lane 7: testis, lane 8: mammary gland, lane 9: prostate, lane 10: ovary, lane 11: uterus. of the primary tumor, feline Brca 2 mRNA expression might also be a prognostic factor in feline mammary tumors.

ACKNOWLEDGMENT. This work was supported in part by Grants-in-Aid for Scientific Research (15208030, 15380201, 11460133) from the Ministry of Education, Culture, Sports, Science, and Technology of Japan.

\section{REFERENCES}

1. Arnaudeau, C., Helleday, T. and Jenssen, D. 1999. J. Mol. Biol. 289: 1231-1238.

2. Bieche, I., Nogues, C. and Lidereau, R. 1999. Oncogene 18: 5232-5238.

3. Bignell, G., Micklem, G., Stratton, M. R., Ashworth, A. and Wooster, R. 1997. Hum. Mol. Genet. 6: 53-58.

4. Chen, P. L., Chen, C. F., Chen, Y., Xiao, J., Sharp, Z. D. and Lee, W. H. 1998. Proc. Natl. Acad. Sci. U. S. A. 95: 52875292.

5. Connor, F., Smith, A., Wooster, R., Stratton, M., Dixon, A., Campbell, E., Tait, T. M., Freeman, T. and Ashworth, A. 1997. Hum. Mol. Genet. 6: 291-300.

6. Dorn, C. R., Taylor, D. O., Schneider, R., Hibbard, H. H. and Klauber, M. R. 1968. J. Natl. Cancer Inst. 40: 307-318.

7. Egawa, C., Miyoshi, Y., Taguchi, T., Tamaki, Y. and Noguchi, S. 2002. Int. J. Cancer 98: 879-882.

8. Fuks, F., Milner, J. and Kouzarides, T. 1998. Oncogene 17: 2531-2534.

9. Gayther, S. A., de Foy, K. A., Harrington, P., Pharoah, P., Dunsmuir, W. D., Edwards, S. M., Gillett, C., Ardern-Jones, A., Dearnaley, D. P., Easton, D. F., Ford, D., Shearer, R. J., Kirby, R. S., Dowe, A. L., Kelly, J., Stratton, M. R., Ponder, B. A., Barnes, D. and Eeles, R. A. 2000. Cancer Res. 60: 4513-4518.

10. Hahn, K. A., Bravo, L. and Avenell, J. S. 1994. In Vivo 8: 825828.

11. Hayes, H. M., Jr., Milne, K. L. and Mandell, C. P. 1981. Vet. Rec. 108: 476-479.

12. Kollias, J., Man, S., Marafie, M., Carpenter, K., Pinder, S., Ellis, I. O., Blamey, R. W., Cross, G. and Brook, J. D. 2000. Breast Cancer Res. Treat. 64: 241-251.

13. MacEwen, E. G., Hayes, A. A., Harvey, H. J., Patnaik, A. K., Mooney, S. and Passe, S. 1984. J. Am. Vet. Med. Assoc. 185: 201-204.

14. Morimatsu, M., Donoho, G. and Hasty, P. 1998. Cancer Res. 58: $3441-3447$.

15. Ochiai, K., Morimatsu, M., Tomizawa, N. and Syuto, B. 2001. J. Vet. Med. Sci. 63: 1103-1108.

16. Rahman, N. and Stratton, M. R. 1998. Annu. Rev. Genet. 32: 95-121.

17. Rutteman, G. R., Withrow, S. J. and MacEwen, E. G. 2001. pp. 455-477. In: Small Animal Clinical Oncology, 3rd ed. (Withrow, S. J. and MacEwen, E. G. eds.), W. B. Saunders Co., Philadelphia.

18. Sharan, S. K. and Bradley, A. 1997. Genomics 40: 234-241.

19. Sharan, S. K., Morimatsu, M., Albrecht, U., Lim, D. S., Regel, E., Dinh, C., Sands, A., Eichele, G., Hasty, P. and Bradley, A. 1997. Nature (Lond.) 386: 804-810.

20. Takata, M., Tachiiri, S., Fujimori, A., Thompson, L. H., Miki, Y., Hiraoka, M., Takeda, S. and Yamazoe, M. 2002. Oncogene 21: 1130-1134.

21. Tavtigian, S. V., Simard, J., Rommens, J., Couch, F., ShattuckEidens, D., Neuhausen, S., Merajver, S., Thorlacius, S., Offit, 
K., Stoppa-Lyonnet, D., Belanger, C., Bell, R., Berry, S., Bogden, R., Chen, Q., Davis, T., Dumont, M., Frye, C., Hattier, T., Jammulapati, S., Janecki, T., Jiang, P., Kehrer, R., Leblanc, J. F., Goldgar, D. E. et al. 1996. Nat. Genet. 12: 333-337.

22. Wagner, T. M., Hirtenlehner, K., Shen, P., Moeslinger, R., Muhr, D., Fleischmann, E., Concin, H., Doeller, W., Haid, A., Lang, A. H., Mayer, P., Petru, E., Ropp, E., Langbauer, G., Kubista, E., Scheiner, O., Underhill, P., Mountain, J., Stierer, M., Zielinski, C. and Oefner, P. 1999. Hum. Mol. Genet. 8: 413-423.

23. Warren, M., Smith, A., Partridge, N., Masabanda, J., Griffin,
D. and Ashworth, A. 2002. Hum. Mol. Genet. 11: 841-851.

24. Weijer, K., Head, K. W., Misdorp, W. and Hampe, J. F. 1972. J. Natl. Cancer Inst. 49: 1697-1704.

25. Wong, A. K., Pero, R., Ormonde, P. A., Tavtigian, S. V. and Bartel, P. L. 1997. J. Biol. Chem. 272: 31941-31944.

26. Wooster, R., Bignell, G., Lancaster, J., Swift, S., Seal, S., Mangion, J., Collins, N., Gregory, S., Gumbs, C. and Micklem, G. 1995. Nature (Lond.) 378: 789-792.

27. Yano, K., Morotomi, K., Saito, H., Kato, M., Matsuo, F. and Miki, Y. 2000. Biochem. Biophys. Res. Commun. 270: 171175. 